\title{
Using Readers Theater as a Facilitator in Elementary School English Training
}

\author{
Ya-Fen Lin \\ ${ }^{1}$ Applied English Department, Overseas Chinese University, Taichung City, Taiwan R.O.C. \\ Correspondence: Dr. Ya-Fen Lin, Applied English Department, 100, Chiao-Kwang Rd. Taichung City, Taichung \\ City, Taiwan R.O.C. E-mail: yafenus2002@gmail.com
}

Received: November 8, 2014

Accepted: Feburary 5, 2015

Online Published: May 29, 2015

doi:10.5539/jel.v4n2p43

URL: http://dx.doi.org/10.5539/jel.v4n2p43

\begin{abstract}
The purpose of the study aimed to investigate the effect of the Readers Theater (RT) training on elementary school students. In particular, changes in the students' English reading comprehension before and after the RT show, comparison of the students' responses to English learning, especially English reading, the students' opinions on the RT activities, and the students' responses to English books were examined and analyzed. Additionally, the students' cooperative learning during the RT training was explored.

The subjects of the study were 32 students in the sixth grade of a Taichung elementary school. Thirty-two students participated in RT training for almost forty-four days in order to perform in an RT show. Before the RT training, the subjects were requested to take the standardized English proficiency pretest and pre-study questionnaire. While participating in the RT training, the subjects needed to finish reading the selected English scripts. In the process of reading English scripts, the subjects were engaged in the reader's theater activities, including reading English scripts aloud, performing on the stage, and group work. After the RT training, the subjects were asked to take the standardized English proficiency posttests and post-study questionnaires.

Considering the study findings, it was suggested that the teachers were able to utilize the RT activities in instructing students' English reading. With the stimulation of the RT activities, students could be motivated to be engaged in appreciating English books and obtained meaningful experiences from the characters in the plot. In addition, the teachers could foster students' cooperative learning through group work and enhanced the students' interest in learning English.
\end{abstract}

Keywords: readers theater, English RT Show, cooperative learning

\section{Introduction}

Readers Theater (RT) is literature-based oral reading which communicates story through oral interpretation rather than through acting. It is a form of dramatic presentation. Students expressively read a text or portion of text for an audience. It is similar to a play, but there are generally no costumes, sets, or props and no movements around a stage or action between performers. Moreover, there is no memorization. Scripts are held by the performers. Any memorization is a natural outcome of repeated readings. Simply, it is a dramatic reading of a selection.

In 2005, Lynch-Brown and Tomlinson (as cited in Huang, 2007) pointed out that RT is the oral presentation of literature containing abounding narration and facial expression, so the performance of a RT is an appropriate opportunity for students to practice their oral and expressive abilities. The advantages of RT have indeed resulted in its valid and convenient implementation in the language classrooms based on the benefit of reading aloud in groups. Because of rich narration and expression in RT, it can enable students to be more involved in reading activities with interest.

Furthermore, the goal of RT is to make students substitute for the voices of the characters and enliven them. Engrossing in reading with rich narration and facial expression by holding the script is focused on by preparing of RT. In addition, Liu (2000) noted that while writing scripts, preparing repeated rehearsals, and performing RT on the stage, students in groups do not feel isolated and alone when they are not able to cope with difficulties. They are actively stimulated to interact with the other group members. Besides, the empathy with the characters of the selected reading materials should be familiar to EFL readers. As confirmed by Ronnqvist and Sell (1994), 
teenagers like the books because the characters' thought and feelings are familiar and authentic to teenagers. Reading books can become an access for teenage readers to mirror their life.

Overall, RT is a good tool to use with elementary students. Children who were initially afraid to read in front of their classmates become confident in front of an audience that included family, friends, and strangers. It gives them a positive first experience of being in front of a group and will help them with future public speaking. It also gives students another outlet for the creative play that young children are so good at doing.

The main purpose of RT is that it can improve students' English ability in order to meet the tendency of the international global village. The emphasis of performing contest includes the explanation of scripts and representation of the story, pronunciation, intonation, facial expression, voice, and team spirit and interaction.

In order to avoid obscuring the main purpose of RT, exaggerated props the background of the stage, and extra music are prohibited, but it is acceptable to use props in small size, such as clappers and the uncomplicated clothing styles. According to the performance of citywide RT show of elementary schools during 2009 and 2013, most references to scripts were based on the fairy tales.

With a view to help elementary students open a window on reading, the RT was conducted on elementary school campus. Aged ten to twelve elementary school students were required to perform readers theaters based on students' school English curriculum. Specifically, the purposes of the study are listed as follows:

1) To evaluate elementary students' English proficiency before and after the RT show.

2) To investigate the effects of the RT training on elementary students' responses to English learning, especially English reading.

3) To probe elementary students' opinions on the RT activities.

4) To examine elementary students' cooperative learning according to the team performance in the RT contest.

Grade four to six students are requested to integrate readers theaters into their curriculum and attend the citywide RT contest. Primary students of age 12 are encouraged to recite stories and role play, hence readers theater is a good tool to facilitate English learning in four skills (Lee, 2010). Some college English majors helped tutor and train these students. After getting the consent forms of the principal, English teacher, and parents, the researcher was permitted to conduct this research to investigate the effects of RT on students' proficiency. By implementing the RT and English materials in the elementary students' English instruction, the five research questions are addressed as follows:

1) How do elementary students perform English proficiency test before and after the RT training?

2) How do elementary students change their responses to English learning, especially English reading before and after the RT training?

3) How do elementary students react to the RT activities?

4) How do elementary students respond to cooperative learning judging from the team performance in the RT contest?

\section{Literature Review}

RT has some benefits for four language skills, including listening, speaking, reading, and writing. RT attracts students' interest and attention through drama. The most important thing, RT offers a visual, oral, and audio stimulus for students. Before they have a fresh experience of reading literature, students cannot enjoy reading and appreciating literary texts under such a rich learning condition. It incorporates all four skills, literary materials, and provides motivation for students in a communicative context (Flynn, 2004; Kelleher, 1997). In other words, RT can improve listening, speaking, reading, and writing skills (Huang, 2006; Huang, 2007; Lee, 2010; Tian \& $\mathrm{Wu}, 2012)$.

It is necessary to have active responses for speakers during presentation to develop the listening ability. Listeners should know the meaning right away by listening through the speakers' facial expression, intonation, emotion, and so on. What is more, in order to improve student's listening skills, the natural interactive talk is to stimulate students to use imagination in listening. It has positive influence on listening development when the speakers present the story by natural interaction with listeners (Grugeon, Hubbard, Smith, \& Dawes, 1998; Ur, 1984).

RT performs a plot of meaning-making for the aim of communication and, spiriting with an audience (Neelands, 1984). Listener can predict the plot and tone in a dialogue (Grugeon, Hubbard, Smith, \& Dawes, 1998; Haycraft, 1978; Spolin, 1986). Therefore, it can stimulate students to enlighten their speaking and listening development in RT storytelling. 
In addition, Marcus (2002) stated that reading aloud to the students was a key to help them obtain information. Because of their performance with lots of facial expression, students are attracted to involve in the plot of the story. In other words, the performing actors let the audience students join their responses. What is more, Young and Vardell (1993) found that the student audiences, indeed, benefited from RT. Because students concentrated on the performers' oral reading their listening proficiency were enhanced (Tian \& $\mathrm{Wu}, 2012$ ).

Because RT emphasizes oral and facial expressions, RT can help students enhance their English oral abilities. Students can improve their English speaking by using RT. RT can train student fluency of speaking language and they dare to speak English. Dougill (1987) indicated that the drama activities in classroom could encourage to use their language to speak in the meaningful dialogues. In other words, dramatic activities can let students stay in an authentic situation to communicate with other people. RT, a dramatic activity, students can use English to speak with people fluently. They modify their nervousness to speak in a meaningful situation and to employ stress and intonation and facial expressions. RT can let students play the part of roles, and make them increasingly proficient in speaking. It leads the reluctant students to open their mouth to speak a language.

With perfecting oral reading performances, all students have the opportunity to practice their speaking, little by little increase their confidence in speaking in front of others, and finally succeed in performing the script for an audience (Huang, 2007). Besides, RT emphasizes on not only words, structures, and pronunciation but also thoughts, motivations and comprehension (Miccoli, 2003). Finally, after students use RT, they can make significant progress in oral skills (Tian \& Wu, 2012).

RT can not only help students sharpen their English oral abilities but also encourage students to use their spoken language in a meaningful context. Moreover, the dialogues in dramatic activities provide students with an authentic situation to communicate with each other. Because RT is a dramatic activity, it can let students act out dialogues in front of others and students can overcome their nervousness to speak expressively in a meaningful situation and to employ stress and intonation in language.

In RT, students are divided into groups to rehearse the scripts which are to read aloud rather than memorized. Being a part of the group, they have to practice correct pronunciation, intonation, and expression when reading the text repeatedly. Even for the purpose to make their reading performance better, students are willing to spend extra time practicing oral skills. When rehearsing, students discuss the characters and their characteristics. They talk about what the tones, intonations, and expressions are more suitable for reading and they read the script repeatedly and silently many times during rehearsals. Besides, speaking is concerned with not only words, structures, and pronunciation but also thoughts, motivations and comprehension. When conquering fears and being willing to take risks in speaking in front of others, students make significant progress in improvement of oral skills along with realizing the underlined oral.

Students in RT are inspired to write the script themselves when teachers offer students a script. Latrobe (1996) stated that students felt confident of writing a script based on literary texts. Through writing a script, student should revise and modify their script to the end that they can perform better by a wonderful script. It is not only faithful to the original text but also interesting to the audience. Moreover, if the original text could be a good model for writing, Stewart (1997) suggested that students should be encouraged to write by following the model so that students' writing would be affected by the good model. The instruction of RT script writing was to focus on teaching students how to write down ideas, and how to have the ideas organized in a systematic as well as efficient way (Styles \& Dunn, 1989; Lee, 2010).

Students can communicate what they think and feel by writing. Reading literature and dramatic plays contain extensive usage of vocabulary and sentence structures. It can help students to properly express their own thoughts in oral as well as writing. According to Uthman (2002), each student in the same group was assigned to be responsible for certain pages of the text. Through myriad communication, they decided which parts should be adopted. Finally, students learned to write a good script for their RT performance.

Research has proved the effect of RT on students' writing development (Huang, 2007; Lee, 2010). For example, the adaptation of the RT script could improve student's writing. Groups shared their scripts together and observed their own defects. The last writing can be completed to perform RT through revision. After the groups finished reading aloud, they wrote responses to discuss with the other group members and even the whole class. Students' close attention to dialogues in RT scripts had an influence on their writing. They learn written dialogues develop faster than formal compositions. Thus, students can cultivate writing skills, such as summarizing, deleting, and editing to finish RT scripts (Huang, 2007; Lee, 2010). 
In RT, based on the students' reading, writing the script from the selected stories contains choosing proper quotations, sentences, interpretations, and even conclusions (Liu, 2000). Owing to the thoughtful practices, implementing RT enlivens reading to writing.

In conclusion, by means of RT, experiencing the literary works turns into a meaningful access not only to learning language but merely to enriching personal growth (Young \& Vardell, 1993). During the participation in the processes of RT, students can give the literal words a voice and make the character come alive.

\section{Methodology}

\subsection{Subjects}

Grade four to grade six students are requested to integrate readers theaters into their curriculum and attend the RT contest in Taichung city. Some college English majors helped tutor and train these elementary students in the same neighborhood. After getting the consent forms of the principal, English teacher, and parents, the researcher was permitted to conduct this research to investigate the effects of RT on students' proficiency. The subjects in this study were 32 students in the sixth grade of an elementary school in Taichung. Thirty-two students participated in RT training for almost forty-four days to perform in an RT show. Most students have learned English as a foreign language for at least three years.

\subsection{Instruments}

Two instruments are used to complete the purpose of the study. They are Anglia Ascentis Junior Level as a pretest and a posttest and a pre-study and a post-study questionnaire (Huang, 2007) to the RT for students.

Several standardized proficiency tests are widely used for young learners in Taiwan. Even though these tests all have the equivalent assessment framework to CEFR (Common European Framework of Reference), there are some differences among GEPT (http://www.gept.org.tw/), Anglia Ascentis (http://www.anglia.org/), and STYLE (http://www.cet-taiwan.com/). First, GEPT Elementary Level (CEF A2) is too difficult to elementary students in the reading section. STYLE level 1-4 equals Anglia Ascentis First Step, Junior, and Primary Levels. However, Anglia Ascentis Junior Level is similar to the proficiency levels of fifth and sixth graders in the elementary school curriculum which follows k-9 school curriculum regulated by the Education Department of government (http://www.ftn.ks.edu.tw/b10/eng2.htm). Therefore, Anglia Ascentis Junior was chosen as the pretest and posttest. The purpose of the pretest and posttest is to evaluate the ability of the students between before and after the RT training. The exam had two parts, one was reading comprehension, and the other was listening. The reading comprehension was about to spell, write words, and write about themselves. The listening part was a dictation. Finally, the researchers corrected their answers and scored the test.

The pre- and post-study questionnaires were designed to evaluate participants' responses to English learning, English reading and cooperative learning before and after the RT training.

\subsection{Procedures}

Thirty-two students were taught by one English teacher and ten teaching assistants. The pretest and pre-study surveys were completed on the first day of the training courses. In order to conduct the RT, the students were divided into five groups. The teaching assistants prepared the scripts and distributed the scripts to different groups. These scripts included The Gingerbread Man, The Crazy Critter, The Three Little Pigs, Uptown Mouse and Country Mouse and Cinderella. After the distribution of the scripts, the TAs of the group told them the summary of the scripts. When the students had understood the plot of the script, the TAs asked their members to read it together at the beginning. Then, the TAs guided the scripts to read the script in turns. After taking turns at reading, some students were assigned to play the given roles of the script and read the lines aloud. In addition, each group made a book based on their script by using their imagination. The content includes the lines and illustrations. To facilitate the RT, each member of the group took their individual duty to accomplish the assignment containing cooperatively reading and rehearsing the script.

Thirty-two practiced at least five hours a week with TAs and teacher. After four-four days, each group performed their RTs in front of the teachers and their parents. After the RT shows, the researcher gave the subjects posttest and asked the subjects to fill out the post-study surveys and wrote down their feelings of readers theater. Then, the researcher collected and analyzed the data.

\section{Results}

Data was analyzed quantitatively and qualitatively. The grades of the pretest and posttest, and the student responses to Items 1 to 19 of the pre-study and post-study surveys were analyzed in a quantitative way. The open-ended questions which included Items 20 to 23 of post-study surveys were analyzed in a qualitative way. 


\subsection{Changes in English Reading Comprehension of the Students}

The aim of this section is to research the changes of the students between pretest and posttest. The students took the pretest before RT and took the posttest after RT.

Table 1. Comparison of English proficiency of the students between the pretest and post-test

\begin{tabular}{llll}
\hline Item & & N & Mean \\
\hline English Proficiency & Pretest & 32 & 89.63 \\
English Proficiency & Post-test & 32 & 90.13 \\
\hline
\end{tabular}

According to Table 1, there was no significant difference between the pretest and posttest. With the motivation derived from participating the RT activities, the subjects read aloud the scripts and promoted their reading little by little. Forty-four days was not long enough to cause a significant proficiency change. Longer training time was expected to increase the effect of RT activities on English proficiency.

\subsection{Comparison of the Students' Responses}

This section presents that the student responses to English learning, especially to English reading collected from the pre-study questionnaire and the post-study changed their responses to English learning after forty-four days RT. questionnaire were dissected and discussed to investigate where or not the students

\subsection{Comparison of the Students' Responses to English learning}

Before and After the RT

The effect of the RT on the student responses to English learning was presented in this part. With a view to research the differences in the student responses to English learning before and after RT training, a paired-sample t-test of SPSS was conducted to compare the student responses to Items 1, 2, 3, 4, 5, and 6 between the pre-study questionnaire and the post-study questionnaire. The statistical results are shown in Table 2.

Table 2. Comparison of the student responses to English learning between pre-study and post study

\begin{tabular}{llllll}
\hline Item & Pre- & \multicolumn{3}{c}{ Post- } & Paired-t \\
\hline & $\mathbf{N}$ & $\mathbf{M}$ & $\mathbf{N}$ & $\mathbf{M}$ & $\mathbf{t}$ \\
1. I think learning English is interesting. & 32 & 4.59 & 32 & 4.62 & -0.37 \\
2. I think learning English is important. & 32 & 4.68 & 32 & 4.75 & -1.44 \\
3. I like to learn English listening. & 32 & 4.41 & 32 & 4.47 & 1.00 \\
4. I like to learn English conversation. & 32 & 4.25 & 32 & 4.31 & -1.44 \\
5. I like to learn English reading. & 32 & 4.03 & 32 & 4.09 & 1.00 \\
6. I like to learn English writing. & 32 & 4.00 & 32 & 4.00 & 0.00 \\
\hline
\end{tabular}

As shown in Table 2, there are no significant differences found in the student responses to Item 1, 2, 3, 4, 5, and 6 in the t-tests before and after the RT. The mean score of Item 1 in the post-study questionnaire $(\mathrm{M}=4.62)$ is higher than that in pre-study questionnaire $(\mathrm{M}=4.59)$. The conclusion reflects that after participating in the RT, the subjects thought learning English is interesting. As Gunning (1996) pointed out, reading acted like a trigger for learning languages. Because of the improvement of English reading comprehension, the subjects acquired the sense of achievement in learning English and recognized the significance of English learning.

In regard to the student responses to Item 2, the mean score of Item 2 in the post-study questionnaire $(M=4.75)$ is higher than that in pre-study questionnaire ( $M=4.68$. The result implies that the RT stimulated the subjects to 
learn English. RT was a dramatic activity to attract the students (Prescott \& Lewis, 2003), and the students would be encouraged to be engaged in reading with interest.

Regarding item 3 to item 6, students didn't show any significant increase in the mean scores. However, the mean scores were above average and increased a little bit after the RT training. According to Kelleher (1997), reading aloud of RT was a good way for the students to enjoy the wonderful sounds of the words, so the students were able to be absorbed in learning English listening. In RT training, reading aloud with expressional intonation and rhymes made the subjects pay attention to the performer and listen to plot enthusiastically. Moreover, Flynn (2004) indicated that RT emphasizing the oral and facial expressions to repeatedly rehearse and perform the script, could enhance the students to practice their spoken English.

\subsection{Comparison of the Students' Responses to English Reading}

Before and After the RT Training and Contest

This part indicates the effect of the RT on the student responses to reading English books. For the aim of finding the differences of the student response to English reading before and after the RT, a paired-sample t-test of SPSS was conducted to compare the student responses to Items $7,8,9,10,11,12,13$ and 14 between the pre-study questionnaire and the post-study questionnaire. The consequence of the student responses to Items 7 and 8 are to show the effect of the RT on the students' passion for reading English books. Item 9 and 10 are to examine the students' attitudes for English after reading English books. Items 11, 12, 13, and 14 are to find the differences in the students' intellectual reaction on reading English materials. The statistical results are shown in Table 3.

Table 3. Comparison of the student responses to English reading between pre-study and post study

\begin{tabular}{|c|c|c|c|c|c|}
\hline \multirow[t]{2}{*}{ Item } & \multicolumn{2}{|c|}{ Pre- } & \multicolumn{2}{|c|}{ Post- } & \multirow{2}{*}{$\begin{array}{l}\text { Paired-t } \\
\text { t }\end{array}$} \\
\hline & $\mathbf{N}$ & M & $\mathbf{N}$ & $\mathbf{M}$ & \\
\hline 7. I am active in reading English books. & 32 & 3.78 & 32 & 3.84 & -0.53 \\
\hline 8. I am interested in reading English books. & 32 & 3.87 & 32 & 3.90 & -0.57 \\
\hline $\begin{array}{l}\text { 9. When I read English books, I do not feel } \\
\text { nervous. }\end{array}$ & 32 & 3.84 & 32 & 3.87 & -0.57 \\
\hline 10. I think reading English books is easy. & 32 & 3.84 & 32 & 3.87 & -0.57 \\
\hline 11. I think reading English books is important. & 32 & 4.22 & 32 & 4.41 & -1.65 \\
\hline $\begin{array}{l}\text { 12. I think I should get into the habit of reading } \\
\text { English books. }\end{array}$ & 32 & 4.34 & 32 & 4.38 & -0.57 \\
\hline $\begin{array}{l}\text { 13. I think reading English books can improve my } \\
\text { reading comprehension. }\end{array}$ & 32 & 4.09 & 32 & $4 . .09$ & 0 \\
\hline $\begin{array}{l}\text { 14. I think reading English books can help me } \\
\text { learn English. }\end{array}$ & 32 & 4.00 & 32 & 4.13 & -1.68 \\
\hline
\end{tabular}

Based on Table 3, Item 7 and Item 8 are two important investigations in the student responses which indicate the students' motivations for reading English books. However, it can not be seen that the subjects make students more active attitudes toward reading English books after attending the RT. It is probably because these children were not volunteered to attend RT training.

According to Table 3, there was no significant difference in the student responses to Item 9 and Item 10 which show the students' anxiety on reading English books. Concerning the student responses to Item 9, the mean score of Item 9 in the post-study questionnaire $(\mathrm{M}=3.87)$ is higher than that in the pre-study questionnaire $(\mathrm{M}=3.84)$. The content of English books could be a proper reading material for the subjects to read at ease. Ronnqvist and Sell (1994) noted that the characters, plot, and the theme of books are familiar and authentic to children. Hence, 
the subjects felt close to the issues in the English books. The subjects would not feel anxious about the content once they read English books.

Regarding the student responses to Item 10, the mean score of Item 10 in the post-study questionnaire $(\mathrm{M}=3.87)$ is higher than that in the pre-study questionnaire $(\mathrm{M}=3.84)$. The result indicated that with the appropriate readability of English books, the subjects read English books with fewer comprehension difficulties. This finding is in consistent with Hopper's statement (2006) that the students would consider reading English books to be accessible without being confused about lexical difficulties and grammatical complex.

As shown in Table 3, there are a little differences in the student responses to Item 11 and Item 12, which display the student's intellectual reaction on reading English books. In the student responses to Item 11, the mean score of Item 11 in the post-study questionnaire $(\mathrm{M}=4.41)$ is higher than that in the pre-study questionnaire $(\mathrm{M}=4.22)$. The statistic result infers that the subjects learned the importance of reading books after the RT training. The more English books the subjects read, the more advantage they gained. Therefore, the subjects considered that reading English books was beneficial to their English and personal growth.

In regard to the students responses to Item 12, the mean score of Item 12 in the post-study questionnaire $(M=4.38)$ is higher than that in the pre-study questionnaire $(M=4.34)$. It shows that with some meaningful experiences from the protagonists in the selected fiction, the subjects thought reading English books was worthy to cultivate the habit. As far as the subjects were concerned, getting into the habit of reading English books could be the benefits of their emotional and cognitive cultivation. In other words, reading English books provided the subjects with the emotional and cognitive inspiration. The inspiration makes the subjects expect themselves to face their puberty and future confidently when the students behaved in the reading English books. Research shows that reading English books are worth reading for young students because the books just like a good counselor could guide the young students to figure out solutions to the similar problems happened to the students in books is in agreement with Fuchs' notion (1987). Briefly, it is obvious that reading English books would help the young students to undergo the puberty so that the young students recognize the vital of developing the habit of reading English books.

\subsection{Comparison of the Student Responses to Cooperative Learning Before and After the RT}

This section aims to investigate the student responses to cooperative learning and explore the effect of cooperative learning on the students' English learning. The student responses to Item 15, 16, 17, and 19 collected from the pre-study questionnaire and post-study questionnaire were analyzed with a descriptive statistics of Excel. The statistic results are shown in Table 4.

Table 4. Comparison of the Students' Cooperative Learning between Pre-study and Post Study

\begin{tabular}{llllll}
\hline Item & Pre- & \multicolumn{3}{l}{ Post- } & Paired-t \\
\hline $\begin{array}{l}\text { 15. English classes increase my cooperation with } \\
\text { the other classmates. }\end{array}$ & 32 & 4.44 & 32 & 4.47 & -0.33 \\
$\begin{array}{l}\text { 16. English classes reinforce my interaction with } \\
\text { the other classmates. }\end{array}$ & 32 & 4.00 & 32 & 4.54 & $-1 . .79$ \\
$\begin{array}{l}\text { 17. English classes help me solve problems in } \\
\text { groups. }\end{array}$ & 32 & 4.25 & 32 & 4.28 & 1.0 \\
$\begin{array}{l}\text { 18. English classes provide me with opportunities } \\
\text { to learn English. }\end{array}$ & 32 & 4.47 & 32 & 4.47 & 0 \\
$\begin{array}{l}\text { 19. English classes enhance my interest in } \\
\text { learning English. }\end{array}$ & 32 & 4.41 & 32 & 4.41 & 0 \\
\hline
\end{tabular}

As Table 4 showed, there were three slight differences in the student responses to Item 15, 16, and 17 collected from the pre-study questionnaire and post-study questionnaire. The mean score of Item 15 in the post-study questionnaire $(\mathrm{M}=4.47)$ was higher than that in the pre-study questionnaire $(\mathrm{M}=4.44)$. The statistic result implies that the students agreed strongly group work in the RT created the opportunities to cooperate with other classmates. The finding is in accordance with Johnson and Johnson' statement (1999) that in the group, the students should work as a group. Each of members in the group had to accomplish the same goal by sharing, 
discussing, negotiating, and communicating with one another. Therefore, the students in RT were interdependent until they fulfilled their performance of the RT script.

Regarding the student responses to Item 16, the mean score of Item 16 in the post-study questionnaire $(\mathrm{M}=4.54)$ was higher than that in the pre-study questionnaire $(\mathrm{M}=4.00)$. Judging from the result, it is apparent that cooperative learning cast a significant influence on the subjects' interaction with others. In other words, working with other students in a group enlivened the relationship among students.

As to the student responses to Item 17 , the mean score of Item 17 in the post-study questionnaire $(M=4.28)$ was lower than that in the pre-study questionnaire $(\mathrm{M}=4.25)$. Based on this difference, it reveals that cooperative learning did not cast an impact on the subjects' problem-solving. Maybe the problems students met were just a few, so they did not need to handle them. Hence, the students could not acquire problem-solving skills by means of cooperating with other classmates.

According to the results of Item 18 and Item 19, students did not show any increase or decrease in the mean scores, which displays the training of RT did not truly provided them with opportunities to learn English and did not enhance them interest in learning English.

Regarding Item 20, the average year of learning English was 3.5 years. Thirty-seven percent of the participants enjoyed appreciating performance of classmates and $29 \%$ of the participants enjoyed reading aloud. On the other hand, $21 \%$ of the participants' favorite part of RT was cooperating with classmates and only $8 \%$ of the participants enjoyed writing the RT scripts. One hundred percent of the subjects liked RT activities with classmates in class.

\section{Conclusions}

According to Grade Four to Grade Six English curriculum benchmarks in reading (http://www.ftn.ks.edu.tw/b10/eng2.htm), primary school students are expected to recite a story, read and understand general contents of simple stories. In terms of benchmarks in speaking, primary school students are expected to role play. Readers theater training is a good activity to help students to meet the requirement of benchmark framework.

On the basis of the data analysis, the major findings of the present study were summarized as follows. First of all, even with the students' passion to read, forty-four days was not long enough to cause a significant proficiency change. Longer training time was expected to increase the effect of RT activities on English proficiency Secondly, with regard to changes in students' responses to English learning, it is apparent that after the RT training, students considered English learning to be more important and interesting. Therefore, RT training made them read English articles loudly, have chances to discuss with the partners, and increase their courage on the stage. Most subjects helped one another in cooperative learning to overcome the difficulties in this project. Besides, they not only improved their English abilities but also gained problem-solving skills through RT training.

Considering the study findings, it was suggested that the teachers were able to utilize the RT activities in instructing students' English reading. With the stimulation of the RT activities, students could be motivated to be engaged in appreciating English books and obtained meaningful experiences from the characters in the plot. In addition, the teachers could foster students' cooperative learning through group work and enhanced the students' interest to learn English. Moreover, on the basis of the results of the study, some suggestions are displayed as follows.

First, the sample size can be increased. Only 32 students participated in the RT training. Because the sample size of the subjects was limited, the findings of the study could not be generalized to other elementary school students. In order to make the further studies reliable and credible, it is recommended that the subjects can be expanded to be from different graders and from different schools in Taichung.

Second, the subjects can be in the older ages, such as junior high school students or senior high school students. Due to their young ages, the subjects were too young to answer the questions of questionnaires and give the proper reasons why they liked RT training or activities. On the other hand, junior high school students are reluctant to participate in any research experiments due to the pressure of competitive senior high entrance exam. To recruit enough junior high school participants would be difficult for researchers in Taiwan.

Third, the researcher can lengthen the time for conducting the study. Owing to the time constraint, the study was conducted in only forty-four days. The effect of the RT training on the students' English reading comprehension cannot be statistically different. Thus, the further studies should prolong the time of implementing the study to obtain an overall sight into the effect of the RT training on the students' English reading comprehension. 
With precious cooperative learning experiences, the subjects increased interactions with other classmates and obtained problem-solving skills. In short, RT training provided students with the opportunities to learn and read English RT scripts is an optional medium integrating with pleasurable cooperative learning activities.

\section{References}

Common_European_Framework_of_Reference. (2015). Retrieved February, 10, 2015, from http://en.wikipedia.org/wiki/Common_European_Framework_of_Reference_for_Languages

Coelho, E. (1992). Jigsaw: Integrating language and content. In C. Kessler (Ed.), Cooperative language learning (pp. 129-152). Englewood Cliffs, NJ: Prentice Hall Regents.

Dougill, J. (1987). Drama activities for language learning. London: Macmillan Publishers Ltd.

Flynn, R. M. (2004). Curriculum-based readers theatre: Setting the stage for reading and retention. The Reading Teacher, 58(4), 360-365. http://dx.doi.org/10.1598/RT.58.4.5

Grugeon, E., Hubbard, L., Smith, C., \& Dawes, L. (1998). Teaching speaking and listening in the primary school. London: David Fulton Publishers.

Gunning, T. G. (1996). Creating reading instruction for all children. Boston: Allyn \& Bacon.

Haycraft, J. (1978). An introduction to English language teaching. England: Longman Group Ltd.

Hopper, R. (2006). The god, the bed and the ugly: Teachers' perception of quality in fiction for adolescent readers. English in Education, 40(2), 55-70. http://dx.doi.org/10.1111/j.1754-8845.2006.tb00791.x

Huang, K. L. (2006). Research of Teaching Chinese Language with Readers Theatre for Sixth-Grade Elementary School Students (Unpublished master's thesis). National Tainan University.

Huang, S. C. (2007). A window on reading: Conducting a reader's theater based on adolescent literature reading program in English classes in junior high school (Unpublished master's thesis). National Kaohsiung Normal University.

Johnsonn, D. W., \& Johnson, R. T. (1999). Making cooperative learning work. Theory into Practice, 38(2), 67-73. http://dx.doi.org/10.1080/00405849909543834

Kelleher, M. E. (1997). Readers' theatre and metacognition. The New England Reading Association Journal, $33(2), 4-12$.

Latrobe, K. (1996). Encouraging reading \& writing through readers theatre. Emergency Librarian, 23(3), 16-20.

Lee, Y. H. (2010). A Case Study of Reader's Theater Based on Adapted Literary Works in An Elementary Bilingual Class.(Unpublished master's thesis). National Kaohsiung Normal University.

Liu, J. (2000). The power of readers theater: From reading to writing. ELT Journal, 54(4), 354-361. http://dx.doi.org/10.1093/elt/54.4.354

Marcus, I. (2002). Using storytime to teach information skills. Library Talk, 15(4), 12-14.

Miccoli, L. (2003). English through drama for oral skills development. ELT Journal, 57(2), 122-129. http://dx.doi.org/10.1093/elt/57.2.122

Neelands, J. (1984). Making sense of drama: A guide to classroom practice. Oxford: Heinemann Educational Books Ltd.

Olsen, R. E., \& Kagan, S. (1992). About cooperative learning. In C. Kessler (Ed.), Cooperative language learning (pp. 1-30). Englewood Cliffs, NJ: Prentice Hall Regents.

Prescott, J. O., \& Lewis, M. (2003). The Power of reader's theater. Instructor, 112(5), 22-28.

Ronnqvist, L., \& Sell, R. D. (1994). Teenage books for teenagers: Reflections on literature in language education. ELT Journal, 48(2), 125-132. http://dx.doi.org/10.1093/elt/48.2.125

Slavin, R. E. (1990). Cooperative learning. Boston: Allyn and Bacon.

Spolin, V. (1986). Theater games for the classroom: A teacher's handbook. Evanston, Illinois: Northwestern University Press.

Stewart, L. T. (1997). Reader theatre and the writing workshop: Using children's literature to prompt students writing. The Reading Teacher, 51(2), 174-175.

Styles, M., \& Dunn, J. (1989). Mission to hell. In M. Styles (Ed.), Collaboration and writing (pp. 9-15). Philadelphia: Open University Press. 
Tian, S. P., \& Wu, N. T. (2012). Reader theater as a ticket to more then reading flency: A study of student interaction and perception. National Taiwan University of Science and Technology, Journal of Liberal Arts and Social Sciences, 8(2), 97-118.

Ur, P. (1984). Teaching listening comprehension. Cambridge: Cambridge University Press.

Uthman, L. E. (2002). Reader's theatre. Teaching PreK-8, 32(6), 56-57.

Young, T. A., \& Vardell, S. (1993). Weaving readers theatre and nonfiction into the curriculum. The Reading Teacher, 46(5), 396-406.

\section{Copyrights}

Copyright for this article is retained by the author(s), with first publication rights granted to the journal.

This is an open-access article distributed under the terms and conditions of the Creative Commons Attribution license (http://creativecommons.org/licenses/by/3.0/). 